\title{
Peningkatan Kompetensi pada Siswa Sekolah Menegah Kejuruan Mandiri Melalui Program Pemagangan ke Jepang
}

\author{
Rismaja Putra \\ Program Studi Teknik Manajemen Industri Akademi Teknik Indonesia Cut Meutia, \\ Indonesia
}

Diterima: Mei 2019; Disetujui: Mei 2019; Dipublikasi: Mei 2019;

*Corresponding author: putra.jissho@yahoo.com

\begin{abstract}
Abstrak
Melalui program pemagangan ke jepang siswa SMK Mandiri dapat meningkatkan SDM yang berkualitas, terampil. Disiplin dan memiliki moral kerja yang baik,kembali ke tanah air dapat membantu mewujudkan harapan perusahaan-perusahaan dalam meningkatkan produksi.kompetensi yang di peroleh dinegara maju dapat dikembangkan di Indonesia yang dapat membantu tumbuhnya perkemebangan ekonomi melalui tunjangan yang diperoleh selama tiga tahun di jepang yang dapat dijadikan modal usaha mandiri dan dapat menciptakan lapangan pekerjaan demi kesejahteraan dan kemakmuran bangsa.

Kata Kunci : Terampil,disiplin dan bermoral
\end{abstract}

How to Cite: Rismaja Putra (2019) Peningkatan Kompetensi Pada Siswa Sekolah Menegah Kejuruan Mandiri Melalui Program Pemagangan Ke Jepang. JIME (Journal of Industrial and Manufacture Engineering), 3(1): 42-50 


\section{PENDAHULUAN}

\section{Latar Belakang Masalah}

Sekolah Menegah Kejuruan (SMK) merupakan sekolah vokasi tingkat pendidikan menengah yang sejak dari dulu sampai sekarang ini menjadi banyak peminatan yang bertujuan setelah tamat lebih cepat untuk mendapatkan pekerjaan.

Dikarenakan sistem pendidikan dan kurikulum yang diterapkan lebih banyak praktek dibandingkan teori dan lama pendidikan yang relatif tidak begitu lama Cuma 3 tahun.

Namun demikian

untuk menghasilkan lulusan dan sumber daya yang yang berkualitas perlu suatu manajemen dan perencanaan yang baik sesuai yang dibutuhkan oleh dunia industri.

Manajemen adalah ilmu dan seni mengatur proses pememfaatan sumber daya manusia dan sumber-sumber daya lainnya secara efektif dan efesien untuk mencapai suatu tujuan tertentu. Manajeman ini terdiri dari enam unsur $(6 \mathrm{M})$

$$
\text { yaitu }
$$

men,money,methode,materials,machines, $d$ an market.

Unsur men (manusia) ini berkembang menjadi suatu bidang ilmu manajeman yang disebut manajeman sumber daya manusia atau disingkat dengan MSDM yang merupakan terjemahan dari man power manajemant.
Manajemen yang mengatur unsur manusia ini ada yang menyebutnya manajeman kepegawaian atau manajemen personalia (personal manajement)

Peranan MSDM disini untuk mengatur dan menetapkan program kepegawaian yang mencakup jumlah kwalitas, dan penempatan tenaga kerja yang efektif sesuai dengan kebutuhan perusahan berdasarkan job description, job sfecification, job requirement, dan job avaluation.

\section{Rumusan Masalah}

Berdasarkan hasil pengamatan yang dilakukan pada SMK Mandiri Deli serdang, permasalahan yang akan dicari pemecahaannya melalui penelitian ini adalah lulusannya hanya beberapa persen mendapatkan mendapatkan langsung pekerjaan setelah tamat.

\section{Tujuan Penelitian}

Sesuai dengan pokok pembahasan penelitian , maka tujuan yang akan dicapai adalah untuk memperoleh pengalaman dan keahlian melalui program pemagangan dan kerja nyata di negara industri maju di jepang dengan meningkatkan keahlian dan etos kerja serta budaya disiplin orang jepang dan setelah kembali ke indonesia dapat mengisi kebutuhan perusahaan. 
Rismaja Putra, Peningkatan Kompetensi Pada Siswa Sekolah Menegah Kejuruan Mandiri Melalui Program Pemagangan Ke Jepang

\section{Manfaat Penelitian}

Adapun manfaat yang bisa diambil dari penelitian ini adalah :

1. Bagi siswa

Memperoleh pengalaman, etos kerja, disipilin dan finansial

2. Bagi Peneliti

Hasil penelitian dapat dijadikan referensi nyata dalam persoalan SDM yang berkualiatas yangsesuai kebutuhan dunia industri

3. Bagi institusi

Hasil penelitian dapat dijadikan literatur tambahan sehingga memperkaya khasanah ilmu pengetahuan

\section{Batasan Masalah}

Untuk dapat melihat keakuratan layout yang akan dirancang, maka penulis membuat batasan-batasan berikut :

1. Para lulusan SMK mandiri yang ikut program magang ke jepang dapat memperolah pengalaman kerja di dunia nyata dibawah bimbingan lansung oleh instruktur ahli di bidangnya

2. Para lulusan SMK yang ikut program magang ke jepang memiliki etos kerja, budaya disiplin setelah magang selesai

\section{METODE PENELITIAN}

Metode penelitian yang digunakan dalam penelitian ini adalah metode deskriptif, yaitu prosedur pemecahaan masalah yang diselidiki dengan menggambarkan subjek atau objek pada saat sekarang bedasarkan fakta-fakta yang tampak atau sebagaimana adanya. Metode deskriptif dalam penelitian ini akan mengungkapkan pengaruh peningkatan SDM dengan memiliki budaya disiplin dan etos kerja selama magang di jepang yang mendapat bimbingan langsung oleh instruktur orang jepang sendiri yang ahli dibidangnya.

\section{HASIL DAN PEMBAHASAN}

Agar berbagai manfaat program peningkatan SDM melalui pemagangan ke jepang ini dapat dipetik semaksimal mungkin, berbagai langkah perlu di tempuh. Menurut para pakar pelatihan dan pengembangan bidang SDM pada umumnya sudah bersepakat bahwa ada tujuh langkah-lanagkah yang ditempuh yaitu :

1. Penemtuan kebutuhan

2. Penentuan sasaran

3. Penetapan isi program

4. Identifikasi prinsip-prinsip belajar

5. Pelaksanaan program

6. Identifikasi mamfaat

7. Penilaian pelaksanaan program

\section{Penentuan Kebutuhan}

Merupakan kenyataan bahwa anggaran yang harus disediakan untuk 
membiayai kegiatan pelatihan dan kesempatan baik baik pemuda-pemuda di pengembangan SDM merupakan beban Indonesia terutama alumni SMK Mandiri dari sebuah organisasi dan perusahaan. untuk memamfaatkan kesempatan ini artinya pelatihan dan pengembangan melului program pemagangan selama 3 tertentu hanya diselenggarakan apabila tahun. Kesempatan ini saling kebutuhan untuk itu memang ada. menguntungkan dari kedua Negara baik itu Penentuan kebutuhan itu mutlak perlu Negara jepang maupun juga Negara didasarkan pada analisis yang tepat. Indonesia kususnya alumni SMK Mandiri. Analisis kebutuhan itu harus mampu mendiaknosa paling sedikit dua hal, yaitu masalah-masalah yang dihadapi sekarang dan berbagai tantangan yang baru yang diperkirakan akan timbul di masa depan.

Sejak tahun 1994, ketika mentri tenaga kerja bapak Abdul Latif mencanangkan program magang yang pertama ke jepang untuk pemuda-pemuda indonesia dengan tujuan supaya pemua-pemuda di indonesia dapat belajar dan berlatih kerja di jepang dan kembali ke indonesia dapat mengisi kebutuhan industri dan membuka usaha mandiri dari pengalaman yang diperoleh di jepang.

Program ini sampai sekarang ini tetap jalan, malah dengan perubahan kebijakan di negara jepang mulai april 2019 untuk membuka selebar lebarnya kesempatan bagi orang asing untuk dapat magang di jepang.

Dikarenakan di jepang sekrang kekurangan tenaga kerja akibat penduduk jepang dari tahun ke tahun semakin berkurang, disamping itu juga usia tua yang tidak produktif mencapai 40 persen. Hal ini

\section{Penentuan Sasaran}

Berdasarkan analisis akan pelatihan dan pengembangan, berbagai sasaran ditetapkan. Sasaran yang ingin dicapai itu dapat bersifat teknikal akan tetapi dapat pula menyangkut keprilakuan . atau mungkin juga kedua-duanya. Berbagai sasaran tersebut harus dinyatakan sejelas dan sekongkrit mungkin, baik bagi pelatih maupun bagi peserta. Bagi penyelengara pelatihan dan pengembangan gunanya menegtahui sasaran tersebut:

1. Sebagai tolak ukur kelak untuk menentukan berhasil tidaknya program pelatihan dan pengembangan

2. Sebagai bahan dalam usaha menentukan langkah selanjutnya seperti isi program dan metode pelatihan yang akan digunakan.

Bagi para peserta mamfaatnya terutama terlihat pada persiapan dan usaha apa yang mereka perlu lakukan agar memperoleh mamfaat yang sebesar- 
Rismaja Putra, Peningkatan Kompetensi Pada Siswa Sekolah Menegah Kejuruan Mandiri Melalui Program Pemagangan Ke Jepang

besarnya dari pelatihan dan dengan memiliki karyawan yang handal pengembangan yang akan diikuti.

Kejelasan sasaran juga akan sangat dan beritutute baik akan mempegaruhi peningkatan produksi.

berguna dalam hal program pelatihan dan

Penentuan Isi Program pengembangan ternyata dianggap kurang

Telah disinggung dimuka bahwa berhasil terutama sebagai umpan balik bagi bagian yang mengelola sumber daya manusia, baik mengenai progranya maupun mengenai pesertanya. Artinya, agar apabila program pelatihan dan pengembangan sejenis akan diselenggarakan dimasa depan, pihak penyelenggara tidak mengulangi kesalahan yang sama.

Melalui pelatihan kerja atau pemangangan ke jepang ini banyak mamfaat yang didapat oleh peserta juga bangsa Indonesia, seperti memiliki etos kerja yang tinggi, disiplin, penagalan kerja di Negara industry maju dengan serba technology dan juga financial dari tunjangan yang dapat ditabung setiap bulan yang dapat dijadikan modal usaha setelah kembali ke Indonesia.

Dan bila pihak instansi lainya juga seperti perusahaan sangat diuntungkan karena dengan pengalaman pelatihan kerja di jepang yang mendapat bimbingan langsung dari instruktur atau tenaga pelatih yang ahli dibidangnya kebutuhan yang selama ini diharapkan dari perusahaan-perusahaan di Indonesia menjadi kenyataan dan terwujud. Kerena bentuk dan sifat suatu program pelatihan dan pengembangan ditentukan oleh paling sidikit dua factor, yaitu hasil analisis penentuan dan sasaran yang hendak dicapai, baik dalam arti teknikal maupun dalam bentuk keperilakuan yang hendak dicapai melaui suatu teknik belajar yang dianggap peling tepat.

Dalam program pelatihan dan pengembangan harus jelas diketahui apa yang ingin dicapai. Salah satu sasaran yang ingin dicapai adalah mengajarkan ketrampilan tertentu yang pada umumnya berupa ketrampilan baru yang belum dimiliki oleh para pekerja padahal diperlukan dalam pelaksanaan tugas dengan baik. Mungkin pula pelaksanaaan program pelatihan dan pengembangan dimaksudkan untuk mengajarkan pengetahuan baru. Bahkan sangat mungkin yang diperlukan adalah perubahan sikap dan perilaku dalam pelaksanaan tugas. Dalam hal kaitan dengan program pelatihan kerja ke jepang ini, sebelum peserta dikirim ke jepang terlebih dahulu dilakukan seleksi dengan ketentuan yang telah distandarkan untuk peserta magang asing di jepang. Misalnya seperti keaadan 
fisik tidak cacat, mengerti dan mampu tulis baca dan berkomunikasi dalam bahasa jepang, serta memahami budaya jepang. Sebelumnya perlu persiapan terlebih dahulu, mengingat ini dikarenakan orang jepang memiliki keterbatasan dalam berkomunkasi dengan bahasa asing lainnya seperti bahasa inggris dan lain-lain.

\section{Prinsip-Prinsip Belajar}

Pada akhirnya , hasil yang dicapaiah yang dapat digunakan sebagai tolok ukur tentang tepat tidaknya prinsip-prinsip belajar yang diterapkan dalam suatu program pelatihan dan pengembangan. Dengan perkataan lain, yang diharapkan terjadi ialah berlangsungnya proses belajar mengajar dengan cepat karena peserta latihan dan pengembangan merasa bahwa prinsip belajar yang diterapkan tepat.

Dikalangan pakar pelatihan dan pengembangan telah umum diterima pendapat yang mengatakan bahwa pada dasarnya prinsip belajar yang layak dipertimbangkan untuk diterapkan berkisar pada lima hal, yaitu partisipasi,repetisi, relevan, pengalihan dan umpan balik.

Para peserta pelatihan kerja di jepang yang di latih oleh instruktur ahli prinsip belajar dan memahami apa yang dikerjakan menjadikan hala yang sangat penting dan utama, karena industry dijepang menggunakan technology tinggi yang bila ttampa memahami dengan benar apa yang akan dikerjakan akan berakibat fatal. Baik untuk peserta pelatihan sendiri maupun untuk perusahaan dan mesin yang dipakai. Sebelum ditempatkan di industryindustri peserta akan dibimbing penuh selama satu bulan di training center oleh instruktur alhi. Hal ini menjaga supaya pada saat tiba di tempat kerja peserta tidak bingung dan tidak menjadi minumbulkan masalah dengan para pekerja lainnya baik itu orang jepang sendiri maupun orang asing lainnya.

\section{Pelaksanaan Program}

Perlu ditekankan bahwa sesungguhnya penyelenggaraan program pelatihan dan pengembangan sangat situasional sifatnya. Asrtinya, dengan penekanan pada perhitungan kepentingan organisasi dan kebutuhan para peserta, penerapan prinsip-prinsip belajar yang telah dibahas dimuka dapat berbeda dalam aksentuasi dan teknik-teknik tertentu dalam proses belajar-mengajar. Disamping itu, suatu teknik mengajar dapat berupa pelatihan bagi sekolmpok peserta, tetapi berupa pengembangan bagi sekelompok peserta yang lain pada hal sama-sama mengikuti program yang sama.

Ada pegawai yang cuti atau berhenti, rotasi pekerjaan sebagai teknik pelatihan sering digunakan. Menggunakan teknik ini berarti bahwa para pegawai dilatih 
Rismaja Putra, Peningkatan Kompetensi Pada Siswa Sekolah Menegah Kejuruan Mandiri Melalui Program Pemagangan Ke Jepang

mengerjakan beraneka ragam tugas. dikatakan berhasil apabila dalam diri Dengan prinsip pertisipasi dan pengalihan peserta pelatihan dan pengembangan kemampuan, para pegawai pada umumnya tersebut terjadi suatu proses transformasi. tidak menghadapi kesukaran untuk dialih Proses transformasi tersebut dapat tugaskan, baik secara permanen maupun dinyatakan berlangsung dengan baik untuk sementara waktu.

Sistem Magang. Banyak organisasi yang menerapkan system magang dalam program pelatihan dan pengembangan bagi para karyawannya. Pengalaman menunjukkan bahwa system magang dapat mengambil berbagai bentuk, yang, sekali lagi penerapannya, situsional. System magang daspat mengambil empat bentuk. Bentuk pertama ialah seorang pegawai belajar dari pegawai lain yang dianggap lebih berpengalaman dan lebih mahir melaksanakan tugas tertentu. Agar lebih efektif, magang sering dilengkapi dengan kegiatan belajar formal dalam ruang kelas. Bentuk kedua ialah "coaching" melalui mana seorang pimpinan "mengajarkan" cara-cara yang ditunjukkan oleh atasan tersebut "ditiru" oleh pegawai yang sedang mengikuti latihan. Bentuk ketiga ialah dengan menjadikan seorang pegawai baru sebagai asisten pejabat yang lebih tinggi. Tugasnya selaku asisten adalah memahami tugas-tugas orang yang dibantunya.

\section{Penilaian Pelaksanaan Program}

Pelaksanaan suatu program pelatihan dan pengembangan dapat apabila terjadi paling sedikit dua hal, yaitu:

a. Peningkatan kemampuan dalam melaksanakan tugas

b. Perubahan perilaku yang tercermin pada sikap, disiplin dan etos kerja.

Untuk mengetahui terjadi tidaknya perubahan tersebut dilakukan penialain yang. Untuk mengukur berhasil tidaknya, yang dinilai tidak hanya segi-segi teknis saja, akan tetapi segi-segi keperilakuan.

Dengan demikian jelas bahwa penilaian haris diselenggarakan secara sistematik yang berarti mengambil langkah-langkah berikut:

1. Penentuan kriteria evaluasi ditetapkan bahkan sebelum suatu program pelatihan dan pengembangan diselenggarakan dengan tolok ukur yang jelas berkaitan dengan peningkatan kemampuan produktivitas kerja dalam posisi atau jabatan sekarang maupun dalam rangka mempersiapkan para pekerja menerima tugas pekerjaan baru di masa depan.

2. Penyelenggaraan suatu tes untuk mengetahui tingkat pengetahuan, 
keterampilan dan kemampuan para pekerja sekarang guna memperoleh informasi tentang program pelatihan dan pengembangan apa yang tepat diselenggarakan.

3. Pelaksanaan ujian pasca pelatihan dan pengembangan untuk melihat apakah memang terjadi transformasi yang diharapkan atau tidak dan apakah transfromasi tersebut tercermin dalam pelaksanaan pekerjaan masing-masing pegawai.

4. Tindak lanjut yang berkesinambungan. Salah satu tolok ukur penting dalam menilai berhasil tidaknya suatu program pelatihan dan pengembangan ialah apabila transformasi yang diharapkan memang terjadi untuk nkurun waktu yang cukup panjang dimasa depan, tidak hanya segera setelah program tersebut selesai diselenggarakan. Hal ini setelah program tersebut mendapat perhatian karena memang benar bahwa hasil sautu program pelatihan dan, terutama, pengembangan tidak selalu terlihat dengan segera.

\section{SIMPULAN}

Manajemen adalah fungsi yang berhubungan dengan mewujudkan hasil tertentu melalui kegiatan orang-orang . hal ini berarti bahwa sumber daya manusia berperan penting dan dominan dalam manajemen. Peranan MSDM diakui sangat menentukan bagi terwujudnya tujuan, tetapi untuk memimpin unsure manusia ini sangat sulit dan rumit.

Tenaga kerja manusia selain mampu ,cakap da terampil, juga tidak kalah pentingnya kemauan dan kesungguhan mereka untuk bekerja efektif dan efesien. Kemampuan an kecapakan kurang berarti jika tidak diikuti moral kerja dan kedisiplinan karyawan dalam mewujudkan tujuan.

Lulusan SMK Mandiri dengan pengalaman yang diperoleh selama tiga tahun berlatih kerja di jepang dapat menjawab dan mengisi terwujudnya harapan perusahaan-perusahaan di Indonesia pekerja yang memiliki pengalaman dan kecakapan dalam bidangnya yang dapat menunjang peningkatan produksi industry di tempat mereka diterima.

Lulusan SMK Mandiri disamping memiliki pengalaman dan keahlian serta trampil dibidangnya juga memiliki moral kerja, budaya disiplin dan memiliki rasa tanggung jawab dalam bekerja. Memiliki wawasan internasional dapat mengembangkan dan mendorong dan membawa perubahan perusahaan kearah yang lebih maju. 
Rismaja Putra, Peningkatan Kompetensi Pada Siswa Sekolah Menegah Kejuruan Mandiri Melalui Program Pemagangan Ke Jepang

\section{DAFTAR PUSTAKA}

Atmosudirdjo, Prajudi. 1976. Beberapa Pnadangan Umum tentang Pengambilan Keputusan.

Badan Koordinasi Keluarga Berencana Nasional Deputi Bidang Pengawasan. 1984. Pedoman Pengawasan Melekat. Jakarta

Barnard, Chester I.1978. The Function of the Executive, Edisi ke-50. Harvard University Press, Cambridge Massachusetts.

Barnes, M.C. et al. P.A. 1969. Management Conc. Ltd. Company Organization: Theory and practice. London: George Allen \& Unwim Ltd.

Brosur Kadin Jabar. 1988. Total Quality Control and Quality Control Cyrcle. Bandung

Colling, Jean and Ridge Mary Ritchig. 1970. Personnel Management Problems of the Smaller Firm. London: Institute of Management.

Davis, Ralph C. 1951. Fundamental of Top Management. Tokyo: Kogakusha Company Limited.

Dessler, Gary. 1982. Personnel Management, 3rd Edition. Reston Publishing Company, Inc.

Djamaluddin, M. Arief. 1977. Sistem Perencanaan Pembuatan Program dan Anggaran, Suatu Pengantar. Jakarta: Ghalia Indonesia

Drucker, Peter F. 1970. Managing for Results (Economic Tasks and Risk-Taking Decisions). Pan Books Ltd.

1974. Management, Tasks, Responsibility. London: William Heinemann Ltd.

Effendy, Onong Uchjana. 1977. Kepemimpnan dan Komunikasi. Bandung: Alumni

Flippo, Edwin B. 1984. Personnel Management, Sixth Edition. New Work: Mc. Graw-Hill Book Company.

Geroge, Terry R. 1978. Principle of Management, Sixth Edition. Homewood Illionois, Richsard D. Irwin Inc.

Gibson, James L., John Al. Ivancevich and James H. Donnelly Jr. 1984. Organization, 4th Edition. Bussiness Publication, Inc.
Hadipoernomo. 1982. Tata Personalia. Jakarta: Djambatan.

Handoko, T. Hani. 1985. Manajemen. Personalia dan Sumber Daya Manusia. Yogyakarta: Liberty.

Hasibuan, Malayu S.P. 1985. Manajemen, Dasar, Pengertian, dan Masalah. Jakarta: CV Haji Masagung.

1987. Ekonomi Pembangunan dan Perekonomian Indonesia. Bandung: CV Armico.

Hersey, Paul and Ken Blanchard. 1982. Management of Organization Behavior, Utilizing Human Resources, 4th Edition. Prentice-Hall, Inc.

Hicks, Herbert G. and G. Ray Gullit. 1975. Organization Theory and Behavior. Mc. GrawHill.

Humble, John W. 1967. Improving Business Result. Mc. Graw-Hill.

Kepner, Charles H. and Benyamin B. Trogoe. 1965. The Rational Manager. Mc. Graw-Hill.

Koontz, Harold J. and Cyril O Donnel. 1984. Management, Eight Edition. Mc. Graw-Hill. Kogakusha.

Leavitt, Harold J. 1978. Managerial Psychology, Fourth Edition. The University of Chicago.

Lewin, Richard I. and Chrles A. Kirpatrisk. 1966. Planning and Control wich PERT/CPM. New York: Mc. Graw-Hill.

Manulang, M. 1976. Management Personalia. Jakarta: Ghalia Indonesia.

Moekijat. 1983. Management Kepegawaian (Personnel Management). Bandung: Alumni.

Mulyawan D.P. 1976. Hubungan Perburuhan Pancasila. Jakarta.

Musanef. 1983. Manajemen Kepegawaian di Indonesia. Jakarta: CV Haji Masagung.

Hasibuan, Malayu S.P. 2013. Manajemen Sumber Daya Manusia. Edisi Revisi. Jakarta: Bumi Aksara

Siagian, Sondang P. 2010. Manajemen Sumber Daya Manusia. Jakarta: Bumi Aksara 